\title{
PEMIKIRAN MEHDI GOLSHANI TENTANG DIALEKTIKA AGAMA DAN SAINS
}

\author{
Mukhlisin Saad \\ Universitas Islam Negeri Sunan Ampel Surabaya, Indonesia \\ E-mail: mukhlisinsaad@uinsby.ac.id
}

\begin{abstract}
This article seeks to scrutinize Mehdi Golshani's thought on dialectical relation of religion and science. In the history of human being, the relation of religion and science has been dynamically connected. Each side has correlated, dominated, and synergized with one to another. The relation of these two entities has brought about a number of various paradigms, namely theocentric, anthropocentric, and Theoanthropocentric paradigms. Employing bibliographical approach, this study discusses historical relation of religion and science, which has been long connected since the Medieval Century. The study finds that Golshani has founded his conception of science on the basis of dichotomization between what so-called the sacred sciences and the secular one. He has tried to link these two entities by, among others, dialoguing between material aspect and supranatural realm. To him, either religion or science shares a common orientation in order to reach the supreme truth, i.e. God. When religion undergoes the quest through obedience upon the dogmas stipulated by God, science prefers reason to get along with Him. In the meantime religion and science are able to integrate and share with each other. Golshani calls it the Islamic Sciences.
\end{abstract}

Keywords: Religion; sacred sciences; secular sciences; Islamic sciences.

\section{Pendahuluan}

Secara historis, diskursus mengenai hubungan agama dan ilmu pengetahuan (baca: sains) sudah berlangsung dalam periode sejarah yang cukup panjang. Dalam kurun waktu yang panjang tersebut, relasi agama dan sains mengalami berbagai dinamika. Pada momen tertentu, relasi agama dan ilmu pengetahuan berada pada garis persinggungan. Di sini, agama tidak menjalin harmonisasi dengan ilmu pengetahuan. Sebaliknya, agama dan ilmu pengetahuan terjebak dalam hubungan 
oposisi binner. Pada masa ini, agama dengan segala nilai keagungan dan kemagisannya, menjadi satu pandangan dogmatik yang mengambil alih keseluruhan aspek kehidupan masyarakat. Agama memegang kendali di segala lini. Bukan saja pada aspek teologis yang mengatur hubungan manusia dengan Tuhan, namun juga pada aspek lain di luarnya. Bahkan ke ranah kebebasan berpikir dan bernalar sekalipun. Dalam sejarahnya, masa ini dikenal dengan sebutan teosentris (belief age), bahwa ilmu pengetahuan berada di bawah kendali agama. ${ }^{1}$

Sejarah mencatat, disharmonisasi agama dan ilmu pengetahuan pada periode ini telah menyisakan sejarah kelam yang ditandai oleh adanya pertentangan terus menerus antara agamawan dengan ilmuwan. Bahkan dalam banyak kesempatan berujung pada pemberangusan hak asasi manusia. Tidak sedikit kalangan ilmuwan meninggal dunia, lantaran harus berhadapan dengan otoritas keagamaan, yang saat itu memiliki intervensi kuat. Beberapa ilmuwan yang terbunuh pada era ini di antaranya adalah Nicolaus Copernicus yang mati di dalam penjara pada tahun $1543 \mathrm{M}$. Hal itu terjadi setelah teori Heliosenstrisnya berseberangan dengan teori Geosentris gereja. ${ }^{2}$ Hal yang sama pun dialami oleh Michael Servet yang mati dibakar pada tahun 1553 M. Begitu juga dengan Giordano Bruno (1600M). Galileo Galilei pun bernasib sama, yang mati di penjara (1642 M) karena telah membenarkan teori heliosentris Copernicus. ${ }^{3}$

Relasi agama-sains menemukan babak baru setelah memasuki abad 16 M. Pada abad ini, posisi agama sebagai sumber tunggal kebenaran mulai goyah. Agama dengan segala cerita magis dan keagungannya perlahan-lahan kehilangan daya otoritas dan kekuatannya untuk melakukan intervensi. Terjadinya aksi revolosui besar-besaran di Eropa menjadi penanda kemunculan era keruntuhan agama sebagai satu kekuasaan tunggal pada masanya. Revolusi tersebut lahir dalam dua pristiwa besar. Pertama, renaissance (kelahiran kembali), yaitu gerakan perlawanan masyarakat Eropa terhadap otoritarian geraja. Kedua, aufklarung (masa pencerahan), yaitu gerakan yang muncul akibat kekangan dogmatis gereja terhadap kebebasan

${ }^{1}$ John F. Haught, Perjumpaan Sains dan Agama: dari Konfik ke Dialog, terj. Fransiskus Borgias (Bandung: Mizan, 2004), 2.

2 Saifullah, "Renaissance dan Humanisme Sebagai Jembatan Lahirnya Filsafat Modern”, Jurnal Ushuluddin, Vol. 12, No. 2 (2014), 137.

${ }^{3}$ Hermanto Halil, LAD, ISD, dan IBD dalam Perspektif Islam (Pamekasan: Duta Media Publishing, 2015), 49. 
berpikir. Renaissance adalah simbol atas keberadaan masyarakat Eropa pada masa itu, yang berusaha keras membebaskan diri dari era kegelapan di bawah bayang-bayang kejumudan gereja. Kelahiran kembali mengisyaratkan atas adanya peralihan dari dunia lama ke dunia baru. Dari era dogmatis menuju era logis, dari era normatif menuju era dinamis. Dalam perjalanannya, era kelahiran kembali di sini semakin menemukan momentumnya setelah terjadi gerakan revolusi baru yang memiliki semangat sama, yakni aufklarung/enlightment. Masa pencerahan adalah simbol gerakan fajar, di mana masyarakat Eropa mulai menemukan kesadaran setelah sekian lama terninabobokan oleh halusinansi gereja.

Pada gilirannya, dua revolusi di atas menjadi pintu gerbang lahirnya paradigma ilmu pengetahuan dan peradaban di bumikhususnya Eropa-, yang sekaligus menjadi momentum munculnya dominasi hierarki ilmu pengetahuan terhadap bahasa-bahasa agama. ${ }^{4}$ Sebuah paradigma kehidupan baru (baca: modernisme) yang menggantikan tatanan kehidupan masa pertengahan (belief age) yang pada masanya dinilai dogmatis dan penuh kegelapan. Secara umum, paradigma tersebut ditandai oleh lahirnya gerakan humanisasi, modernisasi, dan sekularisasi yang kesemuanya tercermin dalam diktum besar Rene Descartes (1596-1650), Cogito Ergo Sum. Puncak dominasi ilmu pengetahuan lahir seiring terjadinya revolusi ilmu pengetahuan yang mereduksi konsep kebenaran pada formulasi positivisme, kaku dan menekankan empirisme. Pada gilirannya, konsep tentang kebenaran berkembang dalam paradigma antroposentris, ${ }^{5}$ dan menggusur paradigma teosentris. Puncaknya, dunia sains terwujud dalam wajah sekuler. Agama dengan segala bahasa mistik dan kemagisannya mengalami alienasi. Bahasa agama yang serbamistik, gaib, dan transenden dinilai kalangan ilmuwan tidak dapat dijadikan standar kebenaran. Sehingga mereka yang mengklaim diri sebagai penganut aliran ini merasa tidak perlu lagi mengikutsertakan dimensi agama dalam argumentasi ilmiah mereka. Bagi mereka, kepercayaan pada Tuhan telah berhenti menjadi apapun, termasuk menjadi pencipta dan pemelihara alam semesta. ${ }^{6}$ Antroposentrisme dan humanisme secara langsung menasbihkan otak dan pikiran

4 Medhy Aginta Hidayat, Menggugat Modernisme: Mengenali Rentang Pemikiran Postmodernisme Jean Baudrillard (Yogyakarta: Jalasutra, 2012), 35.

5 Mohammad Kosim, "Ilmu Pengetahuan dalam Islam: Perspektif Filosofis Historis”, Jurnal Tadrîs, Vol. 3, No. 2 (2008), 126.

${ }^{6}$ Ibid.,126. 
manusia sebagai sumber tunggal kebenaran, menggeser otoritas agama.

Dalam perkembangan berikutnya, tarik menarik antara agama dan sains yang senantiasa terjebak dalam hubungan dialektika kontradiktif, pada batasan-batasan tertentu menjadi problem tersendiri. Khususnya bagi kalangan agamawan dan cendekiawan yang merasa cukup perihatin terhadap adanya pertentangan agama dan sains. Kekhawatiran ini kemudian mengilhami para pemikir untuk mencari solusi, bagaimana mendudukkan agama dan sains dalam satu sintesa yang berkeseimbangan dan produktif. Berbagai pemikiran pun bermunculan dalam upaya menengahi dan menjembatani keduanya. Dari kelompok saintis, ada nama Charles Percy Snow, disampaikan melalui ceramahnya di Universitas Cambridge yang kemudian dibukukan dengan judul The Two Cultures. ${ }^{7}$ Sedangkan dari kalangan teolog, muncul nama Huston Smith, Ian G. Barbour dengan konsep kesamaan metode antara sains dan agama, ${ }^{8}$ Syed Naquib al-Attas, Ismail Raji al-Faruqi, dan Mehdi Golshani. Empat nama terakhir merupakan teolog Muslim yang berusaha memadukan agama dan sains melalui konsep islamisasi ilmu pengetahuan. Artikel ini untuk selanjutnya akan berupaya mendalami konsep yang dirumuskan oleh Golshani dalam merumuskan relasi agama-sains yang harmonis tanpa menafikan salah satunya.

\section{Sejarah dan Filosofi Relasi Agama dan Sains}

Dialaktika agama dan sains pada dasarnya muncul berdasarkan bangunan dasar mereka yang secara filosofis mempunyai sisi perbedaan yang sangat fundamental. Agama dan sains merupakan ruang otonom, di mana keduanya mempunyai ciri dan karakteristik masing-masing. Baik dalam tataran ontologi, epistemologi, maupun aksiologi. Secara umum, berbagai sisi perbedaan tersebut lahir sebagai konsekuensi logis atas konotasi agama yang lebih dekat dengan bahasa mistis. Sebaliknya, ilmu pengetahuan identik dengan bahasa angka. ${ }^{9}$ Menggunakan asas berpikir yang sistematis dan terstruktur dengan ciri khasnya yang empiris dan verifikatif. Dengan demikian, berlandaskan

\footnotetext{
7 Ian Barbour, Juru Bicara Tuhan antara Sains dan Agama, terj. E.R. Muhammad (Bandung: Mizan, 2004), 54.

8 Indal Abror, "Refleksi tentang Hubungan Sains dan Agama Bagi Umat Islam", Aplikasia: Jurnal Aplikasi llmu-ilmu Agama, Vol. 8, No. 1 (2007), 32.

${ }^{9}$ Huston Smith, Ajal Agama di Tengah Kedigdayaan Sains, terj. Ary Budianti (Bandung: Mizan, 2003), 32.
} 
pada sudut pandang perbedaan ini, maka wajar jika ada banyak kalangan menilai, bahwa ide percampuran antara agama dan sains adalah sebuah kebodohan besar. Dua-duanya harus dibedakan. ${ }^{10} \mathrm{Ilmu}$ pengetahuan membicarakan kebenaran dalam kerangka rasionalempiris. Bahwa apa dan bagaimana konsep tentang kebenaran harus dilandaskan pada penerimaan akal sehat dan berlandaskan pada pengalaman diri secara langsung. Sedangkan agama merumuskan konsep kebenaran berdasarkan pada sifatnya yang revalasionis, yaitu menempatkan wahyu Tuhan sebagai tolok ukur tunggal kebenaran. ${ }^{11}$

Jika dilihat dari sudut pandang filsafat dan logika ilmu pengetahuan, dunia sains mengandung ciri dan sifat yang aposteriori. Sifat aposteriori memuat pengertian, bahwa ilmu pengetahuan hanya membicarakan kebenaran realitas dalam kerangka yang objektif, rasional, logikal, verifikatif, bebas nilai dan terbuka. ${ }^{12}$ Dengan karakteristik tersebut, ilmu pengetahuan mendudukkan diri mereka sebagai satu entitas yang terbuka bagi setiap kemungkinan. Apakah itu berupa kritik, pembenaran, ataupun penyangkalan. Pun demikian dengan bebas nilai tersebut, ilmu pengetahuan memiliki semangat emansipatif yang tidak terikat pada kepentingan dan keberpihakan apapun. Ilmu pengetahuan membicarakan apa adanya. Karakterisk ini mempunyai sisi perbedaan yang cukup mendasar dengan agama. Agama ada dalam wilayah intuitif yang cenderung bersifat apriori. Bahwa realitas dengan segala kebenarannya dapat dinilai benar dan dibenarkan tanpa perlu melakukan pembuktian lebih lanjut. Landasan filosofis inilah yang membuat agama dan sains sulit diakurkan. Karena dalam pandangan dunia sains, setiap gejala sosial yang tidak matematis dan tidak dapat dibuktikan secara verifikatif dan empiris tidak bersifat rasional, ${ }^{13}$ bukan bagian dari fakta. Karenanya, hukum kebenaran dalam agama pun tidak dapat diberlakukan di dalamnya.

Adapun secara historis, hubungan dilaketis antara agama dan sains erat kaitannya dengan sejarah kehidupan Barat. Dapat dikata, Barat dengan segala ragam realitas yang mereka miliki, merupakan rujukan paling jelas untuk memotret dan mengkaji bagaimana dinamika hubungan agama dan ilmu pengetahuan. Maklum saja, secara

\footnotetext{
${ }^{10}$ Franz Magnis-Suseno, Pijar-pijar Filsafat (Yogyakarta: Kanisius, 2005), 12.

11 Bagong Suyanto, dkk, Metode Penelitian Sosial (Jakarta: Kencana Prenada Media Group, 2011), 3.

12 Nyoman Naya Sujana, Berpikir Ilmiah (Jakarta: Kencana Predana Media Group, 2011), 3.

${ }^{13}$ Suseno, Pijar-pijar, 17.
} 
geneologis sejarah pergulatan agama-sains lebih banyak didominasi oleh diskursus kebudayaan dan peradaban Barat. Faktanya, pada kisaran abad pertengahan dan abad-abad sebelumnya, hubungan agama dan sains tercatat kurang baik. Saling bertentangan, bersinggungan, bahkan dalam banyak momentum keduanya terlibat pertarungan hebat yang pada gilirannya berakhir pada pengucilan, penindasan, atau bahkan penerapan hukuman mati. ${ }^{14}$ Secara umum, hubungan agama-sains dalam perspektif sejarah dapat dikelompokkan dalam tiga babakan periode; yakni periode abad pertengahan, periode modern, dan periode postmodern.

1) Abad Pertengahan

Hubungan subordinatif agama-sains, dalam sejarah peradaban manusia, khususnya Barat selaku kiblat ilmu pengetahuan dunia, dapat dilacak pada abad pertengahan (15-16 M). Era ini dikenal sebagai masa kegelapan (the dark age). Secara umum, era ini ditandai oleh cara berpikir manusia yang diikat oleh doktrinasi dan dogma ajaran gereja. Hidup mereka senantiasa dihubungkan dengan tujuan akhir (eschatology). Terdapat keyakinan bahwa segala aspek kehidupan manusia beserta segala misteri di dalamnya pada dasarnya sudah digariskan dan ditentukan oleh jalan kepastian Tuhan. Muara dari kehidupan ini tidak lain adalah mencari keselamatan abadi di kehidupan akhirat kelak.

Semua pemikiran tentang ilmu pengetahuan di era ini secara keseluruhan diarahkan pada aspek teologi. Pemikiran filsafat yang berkembang pada era ini terwujud dalam aliran filsafat scholastic. Yaitu suatu gerakan filsafat yang berlandaskan pada teologi sebagai instrumen utama alat pembenaran dan kebenaran. ${ }^{15}$ Agama, dalam hal ini direpresentasikan oleh uskup dan pihak gereja. Gereja dengan segala kekuatan dan kekuasaannya menempatkan dirinya sebagai satusatunya tolok ukur kebenaran. ${ }^{16}$ Kebenaran mengenai realitas makrokosmos dan mikrokosmos alam semesta beserta isinya, hanya dimiliki oleh kalangan gereja dan kerajaan. Di luar itu tidak ada rumusan kebenaran lain yang boleh diikuti. Mengkritisi-atau lebihlebih menantang pernyataan gereja—adalah wujud pembangkangan atas suara Tuhan (baca: murtad), sehingga baginya harus bertobat. Jika tidak, maka dapat dikenakan hukuman mati. Karena kekakuan dan

\footnotetext{
${ }^{14}$ Smith, Ajal Agama, 201.

15 Saifullah, "Renaissance dan Humanisme", 134.

${ }^{16}$ Donny Gahral Adian, Percik Pemikiran Kontemporer (Yogyakarta: Jalasutra, 2005), 2.
} 
kejumudan inilah, abad pertengahan kerap juga disebut matinya sains. Hal ini dinisbatkan pada realitas kehidupan Barat yang saat itu berada ketat di bawah bayang-bayang pengekangan, matinya akal, dan redupnya ilmu pengetahuan.

Pada masa ini, dapat dipastikan setiap persoalan yang timbul di kalangan masyarakat senantiasa diselesaikan berlandaskan pada otoritas dan kekuasaan pihak gereja. Dalam kaitan ini, Michel Foucault melalui karya monomentalnya, Madness and Civilization (1962), menemukan fakta bahwa pada era ini diskursus kebenaran dan ilmu pengetahuan berada di bawah kontrol dan kekuasaan gereja. Foucault mempertegas temuannya tersebut dengan menelusuri sejarah fanomena kegilaan yang saat itu menjangkiti masyarakat Eropa. Pada abad pertengahan, rezim kebenaran gereja/kerajaan memaknai realitas kegilaan sebagai bentuk dari keterlepasan manusia dari kodrat sejatinya. Pendefinisian tersebut didasarkan dan dipahami sebagai tanda dengan pesan moral yang mengingatkan manusia akan kejatuhan dan pengusiran manusia dari surga. ${ }^{17}$

2) Abad Modern

Pada babakan sejarah selanjutnya, tepatnya pada era modern, pola hubungan agama-sains mulai berbalik arah. Jika pada abad pertengahan agama melakukan hegemoninya pada dunia sains, maka pada kisaran awal $16 \mathrm{M}$ dunia sains mulai menemukan kebebasannya. Hubungan sains-agama pun mulai berubah arah. Sains yang mulanya tunduk pada agama, pada gilirannya secara perlahan dapat mengimbangi agama, bahkan menyingkirkan peran totalitas dogmatis agama. Kelahiran semangat humanisme, modernisme, dan liberalisme menjadi pintu gerbang keluarnya agama dari kesadaran manusia, sekaligus masuknya kedigdayaan akal budi sebagai jalan hidup. Adalah Rene Descartes, melalui diktum besarnya, Cogito Ergo Sum (aku berpikir maka aku ada), menjadi titik awal terbangunnnya manusia dari tidur panjangnya. Dengan diktum ini, ada keyakinan bahwa rasio dengan segala kemampuan dan kelebihannya dinilai dapat mengatasi berbagai persoalan kehidupan yang sebelumnya tidak teratasi oleh kekuatan metafisik. Melalui kekuatan rasio, Descartes memercayai, kepastian kebenaran dapat diperoleh melalui strategi kesangsian metodis. Dengan meragukan segala sesuatu, berbagai misteri tentang

17 Ibid., 87. 
adanya hal yang memunculkan keraguan, kesangsian, dan segala perasaan tanda tanya lainnya, dapat diungkap keberadaannya. ${ }^{18}$

Diktum kebangkitan akal Rene Descartes, dalam perkembangan selanjutnya, berhasil mengilhami kesadaran masyarakat Barat, dan sekaligus mendorong banyak kalangan pemikir barat bersikap kritis. Mereka mempertanyakan dan mempertentangkan kemapanan yang saat itu dipegang sepenuhnya oleh agama beserta institusi bentukannya. Ludwig Feuerbach (1804-1872), memunculkan pemikiran kritisnya terhadap otoritas agama melalui sebuah tesisnya yang berbunyi, teologi adalah antropologi. ${ }^{19}$ Dengan tesis ini, Feuerbach hendak mengatakan bahwa unsur-unsur mistifikasi dan kemagisan yang selama ini diyakini bersemayam dalam diri Tuhan, pada dasarnya juga bersemayam dalam diri manusia. Dengan artian, manusia dengan kemampuan dan kecanggihan daya pikir yang dimiliki, dapat memainkan peran otonom. Manusia dipandang mampu menjawab segala persoalan makrokosmos dan mikrokosmos alam semesta tanpa melibatkan peran Tuhan di dalamnya. Pandangan Feuerbach di sini dilandasi oleh dasar filosofis dirinya yang berakar pada materialisme dialektik, bahwa hakikat dari alam semesta adalah materi. Materi adalah segalanya tanpa campur tangan Tuhan di dalamnya. Satu rupa dengan Ludwig Feuerbach, yaitu Friedrich Nietzsche (1844-1900). Pada masanya Nietzsche membuat gempar pihak kerajaan dan Gereja melalui teriakannya tentang kematian Tuhan, Requiem Aeternam (semoga tuhan beristirahat dalam kedamaian abadi).

Dalam dunia saintis, abad modern sejauh ini disandarkan pada sosok August Comte (1798-1857), filsuf modern sekaligus penggagas aliran paham positivic modernism. Comte menyebut tatanan masyarakat di era ini sebagai satu ciri masyarakat yang menjunjung tinggi pola pemikiran ilmiah. ${ }^{20}$ Masyarakat yang hidup pada masa ini ditandai oleh semakin berkembangnya metode berpikir yang kritis, paradigma pengetahuan yang maju, dan pesatnya produk teknologi yang meluas. Pada ujungnya, lahirnya beragam pandangan baru yang muncul dari akar rasionalisme dan saintisme berhasil mengubah tradisi berpikir masyarakat Barat. Mereka yang dulunya menjadikan bahasa mistik agama sebagai kiblat kebenaran, disebut teosentris, kemudian berpindah haluan kepada kekuatan rasio manusia, disebut

\footnotetext{
${ }^{18}$ Hidayat, Menggugat Modernisme, 3.

${ }^{19}$ Adian, Percik Pemikiran, 2.

${ }^{20}$ Suseno, Pijar-pijar, 11.
} 
antroposentris. Dalam tradisi berpikir yang baru ini, berlaku sebuah logika positivisme, seeing is believing, bahwa benar dalam era seperti ini berada pada pengetahuan inderawi dan berdasarkan pengalaman, bukan pada entitas abstrak dan transenden. ${ }^{21}$ Atas kenyaataan inilah, Karl Marx $^{22}$ sebagai seorang pemikir yang sangat mempercayai kekuatan rasio mengistilahkan agama tidak lebih sebagai candu kehidupan manusia (religion is the opium of the people) yang mengantarkan pemeluknya pada ketertindasan, kemunduran, dan kejumudan hidup yang kaku. ${ }^{23}$ Dalam bahasa yang hampir sama, Sigmund Frued (18561939) menempatkan agama sebagai satu realitas irasional, oudipus comples, $^{24}$ yakni satu ketidakdewasaan dalam berpikir. Kasarnya, mereka yang masih memercayai bahasa agama sebagai pedoman hidup, menurut Frued, sama kedudukannya dengan anak kecil yang belum mempunyai kemampuan berpikir matang.

c) Abad Postmodern

Jika abad pertengahan dikenal sebagai tesis penolakan agama terhadap dunia sains, kemudian era modern dijuluki sebagai antitesis dunia sains terhadap keberadaan agama, maka bisa dikata era postmodern adalah sintesa dari dua kondisi sebelumnya. Postmodern adalah ruang di mana agama dan sains dapat menjalin sinergitas dan keterpaduan. Dua entitas yang sebelumnya saling berseberangan, pada era postmodern keduanya dapat saling mengisi dan menjalin keakuran. Agama tidak lagi mengintervensi keberadaan sains, begitupun sebaliknya ilmu pengetahuan tidak mengebiri nilai-nilai agama. Dalam batasan ini, dapat dibilang hubungan agama dan sains menemukan jalan tengah yang dapat mengakomodir keduanya.

Secara genealogis, hubungan agama dan sains dalam dunia posmodern bermula dari kritik epistemologi mereka terhadap paradigma pembangunan dan tradisi ilmu pengetahuan modern. Kritik epistemologi ini ditujukan pada bangunan narasi besar sains modern yang mempercayai, bahwa segala persoalan sosial-alam yang bersentuhan dengan kehidupan manusia di semua lini dapat diatasi oleh kemampuan akal beserta produknya, ilmu pengetahuan dan teknologi. Fakta atas semakin kompleksnya persoalan alam sosial yang menimpa kehidupan manusia era modern, seperti halnya pencemaran,

\footnotetext{
${ }^{21}$ Ibid., 17.

22 Sunyoto Usman, Sosiologi, Sejarah dan Metodologi (Yogyakarta: Cired, 2004), 31.

23 Erich Fromm, Konsep Manusia Menurut Karl Marx, terj. Agung Prihantoro (Yogyakarta: Pustaka Pelajar, 2004), 5.

24 Adian, Percik Pemikiran, 3.
} 
polusi, pemanasan global, kapitalisasi, neo-kapitalis, dan setumpuk persoalan kesejahteraan manusia, pada kenyatannya telah menimbulkan krisis-krisis kemanusiaan baru karena telah membuat manusia kehilangan dunia metafisiknya. ${ }^{25}$ Dari sinilah kaum kritis postmodernis menilai produk modernisme tidak hanya nihil dari nilai manusiawi (inbuman), tetapi juga telah mengidentifikasi dirinya sebagai instrumen yang menggunakan ilmu pengetahuan untuk melegitimasi status quo dan sistem kekuasaan yang ada. ${ }^{26}$

Menumpuknya krisis alam-sosial, khususnya bencana kemanusiaan modern, pada akhirnya memantik perhatian banyak ilmuwan. Bersamaan dengan kekecewaan kaum kritikus terhadap keberadaan saintisme modern, lahirlah kemudian gerakan pemikiran baru yang memiliki semangat besar melakukan perbaikan konstruksi ilmu pengetahuan. Mereka berpandangan bahwa modernisme adalah satu produk pemikiran yang belum final, melainkan sekadar tahap 'menjadi' (being). ${ }^{27}$ Berbagai ilmuwan dari lintas disiplin berusaha keras mencari jalan keluar, bagimana memgangkat manusia era kini dari krisis alam-sosial modernisme. Hingga akhirnya mereka sampai pada sebuah era baru, postmodernisme. Dalam karyanya yang berjudul, the Postmodern Condition, Jean-Francois Lyotard mengistilahkan postmodernisme sebagai bentuk ketidakpercayaan pada narasi-narasi besar modernisme. ${ }^{28}$ Bagi dirinya, narasi-narasi agung yang dicita-citakan modernisme melalui agenda ilmu pengetahuan dan teknologi tidak lebih sekadar cerita yang mengawang-ngawang (metanarrative), tidak terwujud nyata dalam kehidupan praktis. Dalam pandangan Huston Smith, pangkal dari krisis modernisme tersebut bermuara dari konstruksi filosofis sains modern, yang di satu sisi menjunjung tinggi rasio, dan pada sisi bersamaan menihilkan aspek spiritualitas dan miskin akan metafisis. ${ }^{29}$

Meski secara keseluruhan tidak semua aliran postmodernis memaknai postmodernisme sebagai agenda epistemologis mengintegrasikan agama-sains, namun terdapat titik gradasi yang mempertemukan pemikiran mereka. Bahwa rasio (logos) tidak dapat ditempatkan sebagai tolok ukur kebenaran tunggal. Jacques Derrida,

\footnotetext{
${ }^{25}$ Smith, Ajal Agama, 201.

26 Sindung Haryanto, Spektrum Pemikiran Sosial (Yogyakarta: ar-Ruzz Media, 2012), 297.

${ }^{27}$ Listyono Santoso, Epistemologi Kiri (Yogyakarta: ar-Ruzz Media, 2012), 11.

${ }^{28}$ Haugh, Perjumpaan Sains, 20.

${ }^{29}$ Smith, Ajal Agama, 201.
} 
secara terang-terangan melakukan kritik keras. Dengan tegas dirinya menolak hegemoni rasio dan dominasi ilmu pengetahuan dalam upaya pencarian kebenaran. Jacques Derrida (1930-2004) menyebut cara pikir yang terjebak ke dalamnya sebagai sebagai pola pikir logosentrisme. ${ }^{30}$ Paul Karl Feyerabend (1924-1994), menyebut saintisme modern sebagai anarkisme epistemologi, karena telah didominasi oleh pandangan positivisme. Situasi inilah yang kemudian menjadi pintu gerbang masuknya para pemikir dan tokoh intelektual posmodern, baik yang berlatar teologi, ilmuwan sosial, dan santis, untuk memunculkan gagasan-gagasan baru. Melakukan formulasi agama dan ilmu pengetahuan sebagai dua entitas sosial yang saling melengkapi dan mendukung. Bukan dipertentangkan atau bahkan saling menegasikan satu sama lain. ${ }^{31}$ Satu di antara mereka yang berusaha memperjuangkan pengintegrasian agama dan sains adalah Golshani. Sebelum lebih jauh membahas pemikiran besar Golshani, tentang hubungan agama dan sains, terlebih dahulu akan dijelaskan pola hubungan sains dan agama dalam kerangka lebih luas.

\section{Mehdi Golshani dan Dialektika Agama-Sains}

Diskursus dialektika agama-sains, pada dasarnya telah banyak dimunculkan oleh para pemikir dan kaum filsuf. Khususnya dari kalangan pemikir Barat pada kisaran abad 20, ${ }^{32}$ baik dari kalangan saintis, maupun dari kalangan teolog lintas agama. Jauh sebelum kemunculan era modern, Ibn Khaldūn (1332-1406) sebagai ilmuwan sosial ternama pada masanya, telah mendudukkan term hubungan agama-sains sebagai salah satu tema pokok pemikiran dirinya. Menurutnya, kehadiran ilmu pengetahuan tidak boleh menafikan keberadaan nilai (free value). Baik itu menyangkut nilai moral, nilai agama, ataupun nilai kemanusiaan. Sebaliknya, Ibn Khaldūn menegaskan betapa dunia sains harus mempunyai nilai (laden value), yang memuat visi-misi kebajikan, dan menjunjung tinggi nilai kemanusiaan. Meski pada nyatanya Ibn Khaldūn tidak merumuskan hubungan agama-sains secara eksplisit, namun gagasan laden value yang ia bangun, dalam perkembangan berikutnya menjadi pintu gerbang masuknya agama di dalamnya. Sebut saja Immanuel Kant, seorang

\footnotetext{
${ }^{30}$ Santoso, dkk, Epistemologi, 251.

${ }^{31}$ Ibid., 11.

32 Selvia Santi, "Relasi Agama dan Sains Menurut Seyyed Hossein Nasr dan Ian G. Barbour", Prosiding Konferensi: Integrasi dan Interkoneksi Islam dan Sains, Vol. 1, No. 1 (2018), 1.
} 
filsuf yang turut mengupayakan harmonisasi agama-sains melalui pemikiran besarnya, kritisisme, ${ }^{33}$ atau yang populer dikenal dengan sebutan rasionalisme kritis. ${ }^{34}$

Dalam masa ke masa, diksursus dialektika agama-sains tidak hentihentinya menarik perhatian banyak kalangan. Khususnya kaum cendekiawan yang bergerak di bidang pemikiran keagamaan. Di Barat terdapat nama Huston Smith (1919-2016), seorang teolog yang dikenal aktif mengkritisi perkembangan dunia sains, yang menurutnya sangat mengesampingkan nilai-nilai keagamaan. Kedigdayaan sains yang berkembang begitu pesat, seolah-olah telah memukul mundur agama, bahkan meletakkan agama ke titik nadir. Akar dari persoalan ini, menurut Huston Smith, tidak ada yang lebih krusial kecuali sekularisasi ilmu pengetahuan. ${ }^{35}$ Retaknya hubungan pertemanan agama-sains membuat peran dan posisi agama terpinggirkan. Karenanya, untuk memperbaiki keretakan ini, tidak ada jalan lain kecuali mengembalikan dimensi spiritual ke dalam jiwa ilmu pengetahuan. Menggali dan menelusuri titik temu agama-sains, sehingga pertentangan antar-keduanya dapat dihindari, dan harmonisasi antar-keduanya dapat terwujud.

Selain dari Barat, sebagai embrio lahirnya sains sekuler, kritik epistemologi sains-agama juga datang dari dunia Timur. Satu rupa dengan Huston Smith, kalangan pemikir Timur juga berangkat dari ketidaksetujuan mereka atas konstruksi sekularisme dunia sains. Beberapa di antara mereka adalah Syed Naquib al-Attas, Ismail Raji alFaruqi, dan terakhir adalah Golshani. Berkaitan dengan studi ini, berikut akan dijelaskan pemikiran Golshani berkaitan dengan hubungan sains agama. Untuk memotret pemikiran Golshani secara jelas dan mendalam, maka terlebih dahulu akan dipaparkan biografi pendidikannya.

1) Sketsa Biografis

Mehdi Golshani adalah ilmuwan Muslim asal Iran. Lahir pada tahun 1939, tepatnya di Isfahan. Sebuah provinsi di Iran yang selama ini dikenal sebagai daerah dengan tradisi keilmuannya yang tinggi. Nama Golshani dikenal sebagai cendekiawan dunia, tidak saja sebagai seorang saintis namun juga sebagai pemikir Muslim. Latar keilmuwan

\footnotetext{
33 A. Sony Keraf dan Mikhael, Ilmu Pengetahuan: Sebuah Tinjauan Filosofis (Yogyakarta: Kanisius, 2001), 58-61.

${ }^{34}$ Kosim, "Ilmu Pengetahuan dalam Islam", 126.

35 Smith, Ajal Agama, 119.
} 
sebagai seorang saintis ia mulai ketika dirinya menempuh jenjang sarjana di Universitas Teheran. Masuk sebagai mahasiswa di bidang Fisika (1959). Selepas memperoleh gelar Bachelor of Science (B.S.) dari Universitas Teheran, Golshani muda melanjutkan studinya ke jenjang magister (MA) dan doktor (Ph.D) di University of California (1969), dengan mengambil fokus keilmuan yang sama, yakni fisika. Dengan linieritas keilmuwan yang ditempuhnya, dapat dipastikan bahwa Golshani memiliki kecakapan dan penguasaan keilmuan fisika yang sangat mendalam.

Selepas merampungkan keseluruhan jenjang studinya, Golshani selanjutnya pulang ke negerinya. Ia kemudian aktif dalam dunia akademik sebagai dosen di Universitas Teknologi Syarif. Dengan latar pendidikan serta kepakaran sebagai seorang fisikawan, Golshani kemudian diangkat sebagai Ketua Departemen Fisika selama dua periode, pada 1973-1975 dan 1987-1989. Pernah juga dalam kariernya diangkat sebagai wakil rektor di universitas tempat dirinya mengabdi. Di kancah ilmuwan internasional, Golshani pernah mencatatkan dirinya sebagai ilmuwan Muslim yang diundang oleh Universitas Barkeley, sebagai pembicara dalam forum konferensi internasional, Science and Spiritual Quest (1998). Pada tahun-tahun sebelumnya, dirinya terpilih menerima penghargaan Templeton karena dedikasi dan semangatnya dalam mendalami studi sains dan agama. Puncak dari karier pedidikannya adalah ketika dirinya diangkat sebagai Guru Besar bidang Fisika (1991). ${ }^{36}$ Beberapa karya monumentalnya adalah; The Holy Qur'an and the Science of Nature (1992), From Physics to Metaphysics (1997), Can Science Dispense with Religion? (1998), Science, Religion and Spirituality at the Threshold of the Twenty First Century (2000), dan Issues in Islam and Science (2004).

2) Kontribusi Pemikiran

Dalam babakan sejarah hubungan agama-sains, sosok Golshani dapat dikelompokkan sebagai saintis sekaligus pemikir yang hidup ketika perdebatan agama-sains telah memasuki era kekinian. Jati diri Golshani, yang di satu sisi besar dalam lingkup sains fisika, dan di sisi lain dekat dengan kultur dan paradigma keislaman, membuat dirinya memiliki ketertarikan begitu besar terhadap wacana relasi agama-sains modern. Pandangan Golshani tentang hubungan sains-agama, secara langsung telah melengkapi sekian pandangan dan gagasan

\footnotetext{
36 Ach Syamsuddin dan Maimun, Integrasi Multidimensi Agama dan Sains: Analisis Sains Islam Al-Attas dan Mehdi Golshani (Yogyakarta: IRCiSoD, 2012), 125.
} 
sebelumnya. Hanya, jika dibandingkan dengan pemikir-pemiikir sebelumnya, ada kecenderungan pemikiran Golshani lebih memberi ruang pada keberadaan sains modern, tanpa kemudian menafikan ruang agama di dalamnya. Hal ini dipengaruhi oleh kenyataan latar akademik Golshani, yang lebih banyak berkutat di bidang sains fisika daripada fokus keilmuan lainnya. Secara umum, pandangan Golshani tentang agama-sains relatif berlainan dengan pemikir Muslim lainnya. Sebut saja Ziaudin Sardar, Seyyed Hossein Nasr, Ismail Raji al-Faruqi, dan lain sebagainya. Kendati Golshani dikenal sama kritisnya dengan pemikir lainnya, seperti Seyyed Hossein Nasr, Ismail Raji al-Faruqi, dan Naquib al-Attas, Golshani lebih cenderung menjalankan pemikirannya dengan menawarkan satu penafsiran Islami terhadap keberadaan sains modern. Berbeda dari kebanyakan pemikir lainnya yang lebih cenderung memaksakan diri membangun suatu konsep sains Islam. Gerak pemikirannya semakin menggeliat hebat ketika Golshani dihadapkan pada satu realitas, di mana perbincangan hubungan sains-agama ramai digaungkan oleh banyak pemikir lintas kalangan.

Latar sebagai ilmuwan sains fisika, dalam momen-momen tertentu, membuat Golshani dihadapkan pada kritik. Namun semua kritik tersebut dia jawab dengan kebiasaan dan kemampuan dirinya mengonsumsi sekian banyak literatur keislaman. Terutama kajian keislaman klasik yang bertuliskan Arab. Berkenaan dengan ini, Haidar Bagir dan Zainal Abidin Bagir dalam Taufik Abdullah (2002) menjelaskan, meskipun secara keilmuan, Golshani memiliki gelar akademik sebagai guru besar sains fisika, namun keseharian Golshani sangat akrab dengan buku-buku keislaman. ${ }^{37} \mathrm{Hal}$ inilah yang kemudian menjadi satu keunggulan Golshani dibanding pemikir lain yang mengkaji persoalan relasi agama-sains. Dengan modal keilmuannya ini, Golshani merasa mempunyai tanggung jawab akademik, sekaligus moral sebagai penganut Islam, untuk turut mengambil bagian mencari, menelusuri, dan membangun sebuah konstruksi pemikiran yang dapat mengakomodir sains di satu sisi, dan agama di sisi lain pada saat bersamaan.

Kontribusi terbesar Golshani, kaitannya dengan dialektika agamasains, tercermin jelas dalam pandangan pribadinya, bahwa antara agama dan sains tidak dapat dipertentangkan. Sains dan agama bukan

37 Taufik Abdullah, dkk, Ensiklopedi Tematis Dunia Islam Dinamika Masa Kini (Jakarta: PT. Ichtiar BaruVan Hoeve, 2002), 137-159. 
realitas oposisi binner, di mana satu sama lain saling bersinggungan. Golshani menegaskan, baik agama maupun sains sejatinya memiliki titik gradual, karena keduanya sama-sama dapat menjadi instrumen untuk mengenal dan memahami Tuhan. Menurut Golshani, Allah merupakan kenyataan tertinggi yang menjadi titik pusat segala bentuk aktivitas manusia. Karenanya, meski tidak semua aktivitas kehidupan manusia tidak berwujud ritual ibadah dalam pengertian yang umum, seperti salat, puasa, dan sebagainya, namun ketika hal itu dilakukan untuk mendekatkan diri kepada Tuhan, meningkatkan derajat ketakwaan di sisi Tuhan, maka yang demikian pun akan dicatat sebagai ibadah. Begitupun dengan sains, ketika sains menjadi instrumen untuk mengenali dan memahami kekuasaan Tuhan, maka keberadaannya pun mempunyai kedudukan yang sama dengan ritual ibadah agama pada umumnya. Dalam kerangka inilah, Golshani memandang aktivitasnya selama ini, sebagai fisikawan, adalah bagian dari ibadah. Karenanya, dalam pandangannya tidak ada relasi yang bernuansa konflik atau independen dalam sains dan agama. ${ }^{38}$

Jika ditelusuri lebih dalam, pemikiran Golshani di atas berangkat dari pemahaman dirinya atas hadìth Nabi Muhammad yang berisikan anjuran kepada seluruh umat Muslim untuk mencari ilmu. Dalam pandangan Golshani, baik atau buruk, berharga atau tidaknya sebuah ilmu pengetahuan bukan ada pada entitas dirinya an sich. Namun lebih ada pada apsek penggunaan ilmu pengetahuan, sekaligus kapasitasnya dalam mendatangkan kedekatan pada Tuhan semesta alam. Karenanya, Golshani menjelaskan bahwa setiap ilmu pengetahuan, apa pun itu jenis dan rumpunnya, sepanjang masih memiliki nilai guna bagi kehidupan manusia, mengantarkan manusia menjadi lebih dekat dan mengenal Tuhan, serta dapat meninggikan derajat ketakwaan dan keimanan, maka yang demikian harus dipelajari. ${ }^{39}$ Jika berlandaskan pada penjelasan ini, dapat dikatakan Golshani sangat menentang terhadap sikap dikotomisasi dunia pengetahuan, yang mendudukkan sains dan agama secara hierarkis dan subordinatif.

Berkenaan dengan signifikansi kebermaanfatan sains terhadap keberlangsungan hidup manusia, terutama kontribusinya dalam hal memahami dan mengenal kuasa Tuhan, Golshani dalam Muhammad

\footnotetext{
38 Mehdi Golshani, The Holy Qur'an and The Science of Nature (New York: Global Scholarly Publication, 2003), 39.

39 Mehdi Golshani, From Physics to Metaphysics (Iran: Institute for Humanities and Cultural Studies Publication, 1997), 5.
} 
Thoyib (2013) merumuskannya dalam penjelasan berikut. Bahwa dalam hal kegunaan, sains dengan segala kelebihan dan kecanggihannya dapat memainkan tiga peran berikut, ${ }^{40}$ yakni: Pertama, sains dapat meningkatkan pengetahuan dan pemahaman manusia terhadap Tuhan berserta segala misterinya. Peran ini merujuk pada kecanggihan sains dalam mengungkap sekian banyak misteri alam semesta yang tidak pernah terpecahkan sebelumnya. Bahkan sains dapat menjadi alat pembenaran (verification) terhadap sekian banyak penjelasan agama, kaitannya dengan misteri kehidupan yang ada dalam makrokosmos dan mikrokosmos jagat raya. Kedua, kemampuan sains dalam mengembangkan dan memajukan peradaban Islam secara menyeluruh. Peran ini berangkat dari asumsi bahwa keterbelakangan Islam saat ini berakar dari ketakmampuan mereka menguasai bidang sains. Peradaban Islam akan menjadi maju manakala disertai oleh kuatnya paradigma ilmu sains secara menyeluruh. Ketiga, sains mempunyai fungsi dalam kedudukannya sebagai alat bagi keseluruhan manusia untuk menghadapi tantangan kehidupan. ${ }^{41}$ Dengan kehadiran sains, maka manusia dengan segala keterbatasan dan kelemahannya, semaksimal mungkin dapat terbantu untuk menghadapi segala bentuk aktivitas keseharian mereka.

\section{Sains Islam dan Cita-cita Pengintegrasian Agama-Sains}

Sebelum membahas lebih jauh gagasan integrasi sains-agama Golshani, terlebih dulu penting kiranya mengetahui pandangan Golshani terhadap sains. Dalam pandangan Golshani, sains dipahami sebagai cara untuk memecahkan segala fenomena alam semesta, di mana puncak dari semuanya adalah menginternalisasikan kesadaran diri terhadap keberadaan dan kekuasaan Tuhan semesta alam. Bagi Golshani, fenomena alam semesta yang ada dalam kehidupan manusia tidak sekadar kebetulan, tidak pula terjadi dalam ruang antahberantah. Untuk meyakinkan ini semua, Golshani memberi gambaran jelas, bahwa dalam al-Qur'ān tidak kurang dari 750 ayat yang secara eksplisit menyinggung berbagai fenomena kehidupan manusia. Menariknya, mayoritas dari ayat-ayat tersebut memuat kata perintah kepada umat manusia agar senantiasa merenungi dan

\footnotetext{
${ }^{40}$ Muhammad Thoyib, Model Integrasi Sains dan Agama dalam Perspektif J. F Haught dan M. Golshani: Landasan Filosofis bagi Penguatan PTAI di Indonesia (t.t.: t.tp., t.th.), 13.

${ }^{41}$ Ibid., 45-46.
} 
mempelajarinya. ${ }^{42}$ Karena dengan mempelajarinya, ada harapan manusia dapat mengambil pelajaran, sehingga mengantarkan mereka pada puncak kesadaran terhadap eksistensi Tuhan.

Masih menurut Golshani, sains dan agama tidak dapat dipertentangkan, dan secara alamiah keduanya memang tidak memiliki persinggungan sama sekali. Sebaliknya, sains dan agama mempunyai keterkaitan sangat kuat, bahkan saling mengisi. Itulah mengapa, Golshani menegaskan, sains mutlak untuk senantiasa dihubungkan dengan entitas ketuhanan. Perpaduan sains dengan agama pada gilirannya dapat mengantarkan manusia mengenal Tuhannya lebih dekat. Bagi Golshani, agama melalui kitab sucinya, al-Qur'ān, sekalipun memiliki tingkat kebenaran mutlak, tidak kemudian membuat pembacanya berhenti pada teks suci semata. al-Qur'ān sebagai pedoman utama kaum Muslim, membicarakan fenomena alam semesta berdasarkan garis-garis besarnya saja. Tidak ada penjelasan rinci dalam al-Qur'ān yang menyinggung perihal misteri alam semesta. Penjelasan kitab suci tentang berbagai fenomena kosmologi alam semesta, seperti planet, sistem tata surya, gempa bumi, angin, turunnya hujan, terjadinya siang dan malam, kesemuanya adalah bahasa-bahasa universal al-Qur'ān yang tidak akan bisa dipahami manusia berdasarkan teks suci semata. Dalam konteks inilah sains mendapati peran dan fungsinya. Sains adalah upaya manusia memahami misteri kehidupan alam semesta untuk mengetahui, memahami, dan menyadarkan dirinya atas keberadaan Tuhan semesta alam. Itulah sebabnya, Golshani melihat agama-sains sejatinya sebagai entitas saling melengkapi dan menguatkan. ${ }^{43}$

Jika dikaji lebih mendalam, diskursus agama-sains Golshani pada dasarnya berangkat dari konstruksi filosofisnya yang meyakini bahwa dimensi metafisik memegang peran sentral dalam diri individu. Termasuk dalam hal penguasaan diri terhadap ilmu pengetahuan. Dimensi metafisik atau yang disebut sebagai dimensi ketuhanan merupakan suatu yang paling asasi dari keseluruhan eksistensi di alam semesta. Karena kedudukannya sebagai asas, maka suatu keniscayaan jika kemudian ihwal menyangkut metafisik ini harus dimunculkan dan dijaga keberadaannya. Konsep-konsep tentang alam semesta, baik meliputi sisi makrokosmos hingga mikrokosmos, kesemuanya harus dilandaskan pada perwujudan nilai metafisik. Dalam perspektif ini,

${ }^{42}$ Golshani, The Holly Qur'an, 163.

${ }^{43}$ Ibid., 121. 
kegagalan pembangunan era modern yang menunggalkan paradigma berpikir mereka terhadap kehadiran pengalaman inderawi (empirical expereinces), dapat pahami karena ketakhadiran nilai metafisik di dalamnya. Karena bagi Golshani, tidak ada sains yang murni berwujud empirik, karena setiap kali menginterpretasi data eksperimen bahkan menguji ketepatan data ia selalu bergantung pada konsepsi awal (preconception) dan asumsi sang saintis. ${ }^{44}$ Dalam penjelasan yang sederhana, Golshani menyebut hubungan sains dan agama layaknya pohon dan air. Sains adalah sebuah tetanam pohon yang dahannya tengah dalam keadaan kering, di mana dirinya akan menjadi tumbuh subur manakala disirami oleh agama sebagai airnya. ${ }^{45}$

Konsepsi pengintegrasian agama-sains Golshani berakar dari cara pandangnya yang mengelompokkan sains pada dua kutub berbeda, yakni ilmu sakral (sacred sciences) dan ilmu sekuler (secular sciences). Menurut Golshani, ilmu sakral adalah ilmu yang terbangun berdasarkan pandangan dunia teistik. Yakni menempatkan Tuhan sebegai pusat dari seluruh alam semesta. Tuhan sebagai pencipta dan Tuhan pula sebagai pemelihara. Karena semua berpusat pada Tuhan, maka semua entitas yang ada di dalam semesta menyimpan makna kebesaran Tuhan. Dengan demikian, mempelajari dan memahami segala misteri dan fenomena kealaman, pada dasarnya secara tidak langsung juga mempelajari dan memahami keberadaan, kekuasaan, dan keesaan Tuhan. Sebaliknya, ilmu sekuler adalah kebalikan dari ilmu sakral. Sekuler dalam Kamus Besar Babasa Indonesia (KBBI) memiliki arti bersifat kebendaan atau duniawi. ${ }^{46}$ Yakni ilmu yang dibangun berdasarkan pengabaian diri terhadap keberadaan Tuhan. Baik dalam bentuk sikap, pemikiran, dan tindakan. Ilmu sekuler memiliki paradigma berpikir bahwa agama dan sains adalah ruang berbeda, sehingga keberadaannya tidak dapat dipertemukan. Secara umum, Golshani dalam Samsul Hidayat (2014) mendefinsikan ilmu sekuler dan ilmu sakral sebagai berikut:

Sacred science is one that is framed within a theistic worldview-one that considers God as the Creator and Sustainer of the universe, does not confine the existence to the material realm, believes in a telos for the created world and admits a moral order. Secular science, on the other hand, is indifferent with respect to all these points.

\footnotetext{
44 Thoyib, Model Integrasi Sains, 17.

45 Syarif Hidayatullah, "Relasi Agama dan Sains dalam Pandangan Mehdi Golshani”, Jurnal Filsafat, Vol. 27, No. 1 (2017), 80.

${ }^{46}$ KBBI Online (http:/ / kbbi.kemdikbud.go.id), diakses pada 02 November 2018.
} 
(Sains sakral adalah sains yang terbingkai dalam pandangan dunia yang teistik-pandangan dunia yang menganggap Tuhan sebagai Pencipta dan Pemelihara alam semesta, yang tidak mengurung wujud dalam wilayah material, meyakini pada tujuan bagi alam penciptaan dan mengakui aturan moral. Sains sekular, pada sisi lain, bersifat abai terhadap segenap poin tersebut). ${ }^{47}$

Berkenaan dengan ilmu sekuler di sini, Golshani dalam Syarif Hidayatullah (2017) memberikan beberapa ciri khusus yang membedakan dirinya dari ilmu sakral, ${ }^{48}$ yaitu: Pertama, cara pandang terhadap alam fisik sebagai satu-satunya yang ada atau sesuatu yang diciptakan. Pandangan ini mengisyaratkan atas adanya pola berpikir materialisme. Bahwa apa yang benar dan apa yang nyata adalah suatu ada dalam alam fisik. Hakikat realitas adalah wujud reduksi atas benda-benda kealaman yang keberadaannya dapat diukur, didefiniskan, dilihat, dan berdasarkan pada pengalaman langsung manusia. Konsekuensinya, hal di luar itu, seperti bahasa-bahasa mistik agama beserta turunannya, dianggap sebagai ketidakbenaran dan bukan realitas ilmiah. Kedua, menolak ide adanya tujuan teleologi bagi alam. Bahwa kehadiran alam semesta adalah sebuah kenyataan otonom. Berdiri sendiri tanpa melibatkan Pencipta. Karena sifatnya yang otonom, maka kehadiran alam semesta diyakini tidak memiliki awal dan tidak pula memiliki akhir. Sederhananya, eksistensi alam semesta beserta segala isisnya dinilai sebagai realitas spontan yang tidak mempunyai tujuan. Ketiga, bungkam terhadap makna dan tujuan kehidupan manusia dan tentang moralitas. Poin terkahir ini mengisyaratkan bahwa ilmu sekuler tidak mempunyai kemampuan dan daya diri untuk menciptakan dan menjaga satu tatanan kehidupan yang mengusung semangat moral. Hal ini disebabkan oleh kenyataan miskinnya ilmu sekuler dari muatan nilai-nilai keagamaan, spiritualitas, dan kebajikan. Keempat, sains digunakan untuk mengendalikan dan memanipulasi alam dan masyarakat. Poin ini mengisyaratkan atas keberadaan ilmu sekuler yang dalam kenyatannya seringkali menjadi alat strategis untuk mengeksploitasi lingkungan. Kelima, mengembangkan kekosongan pada nilai atau mengintegrasikan pengetahuan dengan serangkaian nilai. Bahwa ilmu sekuler tidak memiliki ketegasan dalam hal memperjuangkan nilai-nilai kebajikan,

47 Samsul Hidayat, "Sacred Science Vs. Secular Science: Carut Marut Hubungan Agama dan Sains", Kalam: Jurnal Studi Agama dan Pemikiran Islam, Vol. 8, No. 1 (2014), 91.

${ }^{48}$ Hidayatullah, "Relasi Agama dan Sains dalam Pandangan Mehdi Golshani”, 80. 
kemanusiaan, dan nilai etis kehidupan. Konsep free value yang diusung oleh ilmu sekuler menjadikan keberadaannya seolah tanpa arah. Karenanya, Golshani di sini tegas menolak atas konsep free value pada sains. Baginya, semua teori sains, khususnya teori-teori fundamental, pasti melibatkan praanggapan-praanggapan metafisika yang berakar pada world view para saintis bersangkutan.

Dalam penjelasan selanjutnya, setelah Golshani mengklasifikasi ilmu pengetahuan dalam dua kutub berbeda, antara ilmu sakral dan ilmu sekuler, Golshani kemudian menawarkan sebuah pengintegrasian sains-agama, yang ia sebut Sains Islam. Sains Islam dalam bahasa Golshani mensyaratkan atas kenyataan, bahwa setiap konsepsi keilmuwan yang dibangun oleh saintis mustahil bisa terlepas dari model konstruksi berpikirnya. Dengan artian kehadiran dan keberadaan dimensi metafisik secara langsung akan dapat menularkan pengaruh signifikan terhadap bangunan keilmuan yang ia hasilkan. Apa yang disebut dengan nilai-nilai ketuhanan, meliputi keimanan, ketakwaan, religiusitas, spiritualitas, dan kepatuhan diri terhadap Tuhan pencipta alam semsesta, semuanya mempunyai dampak dalam perbuatan, proses seleksi, dan evaluasi sebuah teori. ${ }^{49}$ Secara filosofis, pandangan sains Islam inilah yang kemudian mengilhami Golshani atas tesisnya, bahwa Islam beserta segala perangkat dan nilainya adalah satu elemen integral yang tidak boleh dipisah, apalagi dipertentangkan dengan dunia sains. Di sini Golshani menyebutkan bahwa Islam adalah dasar atau fondasi di mana sains seharusnya diproduksi dan dijalankan dalam kehidupan manusia. ${ }^{50}$

Berkenaan dengan gagasan sains Islamnya, Golshani menyebut empat unsur Islam yang dalam penerapannya dapat menularkan pengaruh terhadap konstruksi keilmuan dan dunia sains secara umum. ${ }^{51}$ Pertama, sifat tunggal Tuhan (tawhid). Tauhid dalam Kamus Besar Bahasa Indonesia (KBBI) mengandung arti keesaan Tuhan. Bahwa semua yang ada di segala penjuru alam semesta ini berakar dari zat tunggal, Tuhan. Semua ada di bawah kekuasaan Tuhan dan pada akhirnya akan kembali kepada-Nya. Begitu pun dengan sains, sains yang dihasilkan manusia dari kegiatan berpikir terhadap fenomena

${ }^{49}$ Mehdi Golshani, Issues in Islam and Science (Tehran: Institute for Humanities and Cultural Studies (IHCS), 2004), 145.

50 Thoyib, Model Integrasi Sains, 50.

51 Zainal Abidin Bagir, Science and Religion in a Post-colonial World (Australia: ATF Press, 2005), 82-87. 
alam semesta sejatinya adalah bagian dari keesaan Tuhan yang dapat berfungsi sebagai manifestasi manusia untuk mengenal dan memahami Tuhannya dalam jarak pemahaman yang lebih dekat. Karenanya, ilmu pengetahuan selain harus mendatangkan kebermanfaatan untuk memudahkan aktivitas manusia, paling fundamental adalah bagaimana dapat memunculkan kesadaran manusia atas eksistensi Tuhannya.

Kedua, Iman terhadap hal yang gaib. Iman berarti meyakini atas setiap entitas berbau supra-natural. Pengakuan terhadap supranatural berarti meyakini atas keterbatasan pengetahuan diri. Bahwa dalam keseluruhan alam semesta ini, apa yang disebut sebagai realitas dan fakta tidak melulu bersifat fisik semata. Di balik itu semua, terdapat realitas lain di luar alam fisik yang keberadaannya tidak bisa dijangkau dan ditangkap oleh indera manusia. Meyakini atas adanya realitas abstrak yang tidak bisa disentuh dan diungkap oleh keseluruhan kemampuan manusia, pada gilirannya dapat menghadirkan kesadaran diri atas keberadaan dan kekuasaan Tuhan semesta alam.

Ketiga, mempercayai atas tujuan akhir semesta. Poin ini mensyaratkan atas adanya kepercayaan dan keyakinan diri bahwa kehadiran alam jagat raya memiliki tujuan dan akhir tertentu. Semesta hadir bukan untuk permainan tanpa tujuan. Melainkan semuanya terjadi atas garis yang dituliskan oleh Allah. Pada masa yang akan datang, semua entitas kehidupan yang terbentang luas di alam semesta akan menemui akhirnya.

Keempat, berpegang teguh pada nilai moral. Unsur terakhir ini mensyaratkan bahwa ilmu pengetahuan, apapun jenis dan rumpunnya, harus memuat nilai-nilai etika dan menjunjung tinggi prinsip-prinsip kemanusiaan-emansipatif. Paling fundamental dari semuanya, ilmu pengetahuan harus dapat menjadikan saintis—meminjam bahasa Hassan Hanafi—pribadi yang memiliki aspek eksistensialisme ideal. Yaitu satu perwujudan jati diri yang berkebebasan hakiki, independen, dan bertanggung jawab. ${ }^{52}$ Dengan independensinya tersebut, maka tidak ada lagi ketergantungan saintis pada dunia materi, alam fisik, dan kebendaan, sebagaimana dalam paradigma ilmu sekuler. Poin ini sekaligus menjadi penegas atas ketidakbenaran karakteristik sains modern yang menekankan pada konsep bebas nilai (free value). Dalam

52 Masduri, "Telaah Kritis Konstrukksi Ekstensialisme dalam Teologi Antroposentris Hasan Hanafi", Islamika Inside: Jurnal Keislaman dan Humaniora, Vo. 4, No. 1 (2018), 51. 
kaitan ini, Golshani meyakini bahwa dalam proses pembangunan sains, empat unsur keislaman di atas menjadi hal yang sangat penting untuk menghasilkan sebuah sains yang tidak saja menawarkan kecanggihan, namun juga mengusung spirit moral dan tanggung jawab. ${ }^{53}$ Sehingga dalam perwujudan dan praktiknya dapat mentransformasikan dua nilai integratif, yakni nilai kemanusiaan di satu sisi, dan nilai ketuhanan pada sisi lainnya.

\section{Catatan Akhir}

Relasi agama-sains dalam sejarah manusia selalu dinamis, kadang berpunggungan, lain waktu saling mendominasi, dan puncaknya saling mengisi. Dinamika ini merupakan proses alami dari kemajuan sejarah manusia. Di abad pertengahan, gereja selaku pihak yang memegang kendali agama berupaya menaklukkan ilmu pengetahuan di bawah dogma agama. Apapun yang diproduksi akal budi manusi tidak boleh bertentangan dengan interpretasi otoritas gereja terhadap wahyu. Di masa itu sains menjadi terbelenggu. Kemudian setelah kekuasaan gereja melemah oleh gelombang revolusi ilmu pengetahuan yang ditandai dengan gerakan renaissance dan aufklarung pada masyarakat Eropa, relasi agama-sains menjadi antagonistik. Keduanya saling menafikan satu sama lain. Era ini kemudian dikenal dengan modernism. Di mana kebebasan nalar sama sekali tidak melibatkan agama dalam menghasilkan sains. Pada saat itu sains benar-benar kering dari nilai dan spiritualitas. Selanjutnya, di era berikutnya paradigm modernisme itu mendapat kritik dari pihak yang merasa ada kekosongan pada sains modern ketika tidak melibatkan agama di dalamnya. Pihak ini menyebut diri sebagai postmodernisme, salah satu tokohnya adalah Golshani yang menawarkan suatu konsepsi tentang integrasi agama-sains.

Gagasan Golshani tentang Sains Islam, hakikatnya merupakan satu wujud upaya epistemologis dirinya untuk ikut turun tangan merespons perdebatan seputar hubungan sains-agama. Sains sebagai hasil pengamatan manusia terhadap sekian gejala alam semesta, merupakan manifestasi diri untuk mengenal dan memahami eksistensi alam semesta. Sains dalam pandangan Golshani bukan semata kumpulan teori, konsep, dan hukum-hukum alam, namun juga merupakan bagian dari kenyataan metafisik yang di dalamnya tersimpan nilai-nilai ketuhanan. Diskursus mencari jalan tengah atas

${ }^{53}$ Ibid.,86. 
perdebatan hubungan sains-agama. Karena sifatnya tersebut, maka sains tidak boleh direduksi pada alam fisik saja (material), namun harus dipadukan dengan alam supranatural (religion).

Gagasan pengintegrasian agama-sains Golshani berpijak pada konstruksi filosofisnya yang memandang ilmu pengetahuan terbagi pada dua kelompok besar, yakni ilmu pengetahuan sekuler dan ilmu pengetahuan sakral. Ilmu sakral adalah ilmu yang memuat nilai teistik. Nilai testik di sini merujuk pada nilai-nilai ketuhanan sebagai bagian integral di dalamnya. Ilmu sakral menjadikan sifat moral dan etika keagamaan sebagai unsur fundamental. Sebaliknya, ilmu pengetahuan sekuler adalah ilmu yang menfokuskan diri pada pengayaan dimensi materi atau fisik, sekaligus menafikan atas keberadaan nilai teistik. Pengintegrasian agama-sains disebut Golshani sebagai Sains Islam yang berpijak pada empat unsur penting yaitu: 1) nilai ketauhidan; 2) kepercayaan pada hal gaib; 3) mempercayai atas tujuan akhir semesta yang semuanya akan berpulang kepada Allah; dan 4) berpegang teguh pada nilai moral. Bahwa keberadaan sains harus dapat memuat dua nilai integral, yakni nilai kemanusiaan di satu sisi dan nilai ketuhanan pada sisi lainnya.

\section{Daftar Rujukan}

Abdullah, Taufik dkk. Ensiklopedi Tematis Dunia Islam Dinamika Masa Kini. Jakarta: PT. Ichtiar BaruVan Hoeve, 2002.

Abror, Indal. "Refleksi tentang Hubungan Sains dan Agama Bagi Umat Islam", Aplikasia: Jurnal Aplikasi Ilmu-ilmu Agama, Vol. 8, No. 1, 2007.

Adian, Donny Gahral. Percik Pemikiran Kontemporer. Yogyakarta: Jalasutra, 2005.

Bagir, Zainal Abidin. Science and Religion in a Post-colonial World. Australia: ATF Press, 2005.

Barbour, Ian. Juru Bicara Tuhan antara Sains dan Agama, terj. E.R. Muhammad. Bandung: Mizan, 2004.

Fromm, Erich. Konsep Manusia Menurut Karl Marx, terj. Agung Prihantoro. Yogyakarta: Pustaka Pelajar, 2004.

Golshani, Mehdi. From Physics to Metaphysics. Iran: Institute for Humanities and Cultural Studies Publication, 1997.

-----. Issues in Islam and Science. Tehran: Institute for Humanities and Cultural Studies (IHCS), 2004. 
-----. The Holy Qur'an and The Science of Nature. New York: Global Scholarly Publication, 2003.

Haryanto, Sindung. Spektrum Pemikiran Sosial. Yogyakarta: ar-Ruzz Media, 2012.

Haught, John F. Perjumpaan Sains dan Agama: Dari Konfik Ke Dialog, terj. Fransiskus Borgias. Bandung: Mizan, 2004.

Hermanto Halil, LAD, ISD, dan IBD dalam Perspektif Islam. Pamekasan: Duta Media Publishing, 2015.

Hidayat, Medhy Aginta. Menggugat Modernisme: Mengenali Rentang Pemikiran Postmodernisme Jean Baudrillard. Yogyakarta: Jalasutra, 2012.

Hidayat, Samsul. "Sacred Science Vs. Secular Science: Carut Marut Hubungan Agama dan Sains", Kalam: Jurnal Studi Agama dan Pemikiran Islam, Vol. 8, No. 1, 2014.

Hidayatullah, Syarif. "Relasi Agama dan Sains Dalam Pandangan Mehdi Golshani”, Jurnal Filsafat, Vol. 27, No. 1, 2017.

KBBI Online (http://kbbi.kemdikbud.go.id), diakses pada 02 November 2018.

Keraf, A. Sony dan Mikhael. Ilmu Pengetahuan: Sebuah Tinjauan Filosofis. Yogyakarta: Kanisius, 2001.

Kosim, Mohammad. "Ilmu Pengetahuan Dalam Islam, Perspektif Filosofis Historis", Jurnal Tadrîs, Vol. 3, No. 2, 2008.

Kosim, Mohammad. "Ilmu Pengetahuan Dalam Islam, Perspektif Filosofis Historis", Jurnal Tadrîs, Vol. 3, No. 2, 2008.

Magnis-Suseno, Franz. Pijar-pijar Filsafat. Yogyakarta: Kanisius, 2005.

Masduri. "Telaah Kritis Konstrukksi Ekstensialisme dalam Teologi Antroposentris Hasan Hanafi", Islamika Inside: Jumal Keislaman dan Humaniora, Vo. 4, No. 1, 2018.

Saifullah, "Renaissance dan Humanisme Sebagai Jembatan Lahirnya Filsafat Modern", Jurnal Ushuluddin, Vol. 12, No. 2, 2014.

Santi, Selvia. "Relasi Agama dan Sains Menurut Seyyed Hossein Nasr dan Ian G. Barbour", Prosiding Konferensi: Integrasi dan Interkoneksi Islam dan Sains, Vol. 1, No. 1, 2018.

Santoso, Listyono. Epistemologi Kiri.Yogyakarta: ar-Ruzz Media, 2012.

Smith, Huston. Ajal Agama di Tengah Kedigdayaan Sains, terj. Ary Budianti. Bandung: Mizan, 2003.

Sujana, Nyoman Naya. Berpikir Ilmiah. Jakarta: Kencana Predana Media Group, 2011. 
Suyanto, Bagong dkk, Metode Penelitian Sosial. Jakarta: Kencana Prenada Media Group, 2011.

Syamsuddin, Ach dan Maimun. Integrasi Multidimensi Agama dan Sains: Analisis Sains Islam Al-Attas dan Mebdi Golshani. Yogyakarta: IRCiSoD, 2012.

Thoyib, Muhammad. Model Integrasi Sains dan Agama dalam Perspektif J. F Hanght dan M. Golshani: Landasan Filosofis bagi Penguatan PTAI di Indonesia. t.t.: t.tp., t.th.

Usman, Sunyoto. Sosiologi, Sejarah dan Metodologi. Yogyakarta: Cired, 2004. 